\title{
Influence of Dry Period Bacterial Intramammary Infection on Clinical Mastitis in Dairy Cows
}

\author{
M. J. Green, ${ }^{\star}$ L. E. Green, ${ }^{\star}$ G. F. Medley, ${ }^{\star}$ Y. H. Schukken, $†$ and A. J. Bradley¥ \\ * Department of Biological Sciences, University of Warwick, Coventry, CV4 7AL, UK. \\ †Department of Population Medicine and Diagnostic Sciences, College of Veterinary Medicine, \\ Cornell University, Ithaca, New York, 14853, USA. \\ ‡Department of Clinical Veterinary Science, University of Bristol, Langford House, Langford, Bristol, BS40 5DT, UK.
}

\begin{abstract}
Milk samples were taken from 1920 quarters (480 cows, six herds) on four occasions to examine the relationship between quarter level intramammary infection (IMI) during the dry period and clinical mastitis in the next lactation. All quarters were sampled at drying off and within $1 \mathrm{wk}$ of calving, and two quarters from each cow were sampled both 0 to 7 and 8 to $14 \mathrm{~d}$ before calving. Milk samples were collected from all cases of clinical mastitis during the following lactation. Logistic regression models were developed to investigate the associations between IMI present during the sampling period and clinical mastitis. The probability of a quarter succumbing to clinical mastitis increased when Streptococcus dysgalactiae, Streptococcus faecalis, Escherichia coli, or Enterobacter spp. were cultured at drying off and when Escherichia coli, coagulase-positive staphylococcus, Serratia spp., or Streptococcus faecalis were cultured in two out of three late dry and post-calving samples. Quarters from which Corynebacterium spp. were isolated at drying off were at an increased risk of clinical mastitis, whereas the presence of Corynebacterium spp. in the late dry and postcalving samples was associated with a reduction in the risk of clinical mastitis. The risk of mastitis for specific pathogens increased if the same species of bacteria that had caused mastitis was isolated at least twice in the late dry and post-calving samples. Kaplan-Meier survival plots indicated that clinical mastitis associated with dry period infections was more likely to occur earlier in lactation than clinical mastitis not associated with dry period infections. There was evidence of quarter susceptibility to IMI or the possibility that infection with one organism led to clinical mastitis with another. (Key words: dry period, intramammary infection, mastitis)
\end{abstract}

Received July 12, 2001.

Accepted April 9, 2002.

Corresponding author: M. J. Green; e-mail: martin@greenl. swinternet.co.uk.
Abbreviation key: 2-C = the time period from $2 \mathrm{wk}$ before calving to $1 \mathrm{wk}$ after calving.

\section{INTRODUCTION}

Clinical mastitis remains a significant problem in UK dairy herds with the current incidence rate estimated at between 40 and 50 cases per 100 cows per year (Kossaibati et al., 1998; Bradley and Green, 2001). This causes significant financial loss to the dairy industry (Kossaibati and Esslemont, 1997) and is an important factor influencing the health of dairy cows.

The importance of the dry (nonlactating) period in the dynamics of IMI in dairy cattle has been studied over many decades (Neave et al., 1950; Oliver et al., 1962; Oliver and Michell, 1983; Smith et al., 1985; Oliver, 1988; Todhunter et al., 1991). Quarters that are infected with bacteria during the dry period produce less milk in the next lactation (Smith et al., 1968) and, therefore, cause financial loss.

Previous field studies have examined IMI in the dry period and during lactation (Eberhart and Buckalew, 1977; Smith et al., 1985; Oliver, 1988; Todhunter et al., 1991), but from these results it is difficult to quantitatively assess the impact of dry-period IMI on clinical mastitis. While not all new dry-period IMI persist through to lactation (Oliver, 1988), there is evidence that some IMI present in the dry period will result in clinical disease in lactation (Neave et al., 1950; Bramley, 1976; McDonald and Anderson, 1981). This has been recently confirmed in the UK with DNA fingerprinting of enterobacterial strains (Bradley and Green, 2001).

A greater understanding of the associations between dry-period IMI and clinical mastitis in the next lactation may assist with the prevention of clinical mastitis. Such associations can only be estimated accurately if the clustered nature of the data is accounted for; quarters being clustered within cows and cows within herds (Goldstein, 1995). Without allowing for clustering, erroneous conclusions may be drawn (McDermott and Schukken, 1994). 
The purpose of this study was to examine the relationship of quarter IMI at drying off and during the dry period, with clinical mastitis in the same quarter, in the next lactation.

\section{MATERIALS AND METHODS}

The method of cow selection and sample collection has been described previously (Bradley and Green, 2001) and is outlined below.

Six herds were selected on the basis of location (Somerset), a 3-mo geometric mean bulk milk SCC under $250,000 / \mathrm{ml}$, nonseasonal calving pattern, and likelihood of owner compliance. Cows that were dried off between 10 February 1997 and 26 January 1998 and calved between 22 March 1997 and 4 April 1998 were recruited to the study. Sample collection ended on 15 July 1998.

Two lacteal secretion samples were collected at each sample time. Samples were taken from all four quarters at drying off and 0 to $7 \mathrm{~d}$ after calving. During the dry period, samples were taken from the ipsilateral quarters (left fore and left hind, odd numbered cows or right fore and right hind, even numbered cows), once 0 to $7 \mathrm{~d}$ and once 8 to $14 \mathrm{~d}$ before the anticipated calving date. Two quarters were left unsampled throughout the dry period as controls. Any cow not calving by her expected date was sampled every week until parturition. During the subsequent lactation, milk samples were collected from all quarters with clinical mastitis identified by the herdspersons who had been previously trained in identification and sample collection. These samples were frozen and submitted once each week to the laboratory for bacteriological analysis.

Teats were thoroughly disinfected, dried, and cleaned twice with surgical spirit before they were sampled, and disinfected after sampling. Milk samples were stored in a cool box immediately after collection and maintained at or below $4^{\circ} \mathrm{C}$. Bacteriology, usually performed within $24 \mathrm{~h}$, was carried out at the Veterinary Laboratory Agency (Langford, UK). Ten $\mathrm{ml}$ of secretion was inoculated onto sheep blood agar and Edward's agar; $100 \mathrm{ml}$ of secretion was inoculated onto MacConkey agar to enhance the detection of Enterobacteriaceae. Plates were incubated at $37^{\circ} \mathrm{C}$ and read at 24 and $48 \mathrm{~h}$. Organisms were identified and quantified using standard laboratory techniques (Quinn et al., 1994). Escherichia coli was identified by colony morphology, oxidase, and indole tests; other Enterobacteriaceae were identified using a microtube identification system (RapiD $20 \mathrm{E}$, bioMérieux, UK).

Dry cow therapy was administered to all cows immediately after collection of the drying off samples. Dry cow products containing cloxacillin (Orbenin Extra,
Pfizer, Sandwich, UK), cephalonium (Cepravin, Schering-Plough, Harefield, UK), or procaine penicillin G (Mylipen, Schering-Plough) were used. Only one of these products was used on any one farm.

\section{Definition of Terms for Analysis}

Days at risk. Quarters were considered at risk from the date of drying off, until $300 \mathrm{~d}$ into the following lactation, unless the cow was censored earlier because the study ended or she was dried off or culled.

Seasonality. Seasons were defined as Winter (Dec., Jan., Feb.); Spring (Mar., Apr., May); Summer (Jun., Jul., Aug.); and Autumn (Sep., Oct., Nov.).

Dry period. The time between the intramammary infusion of dry cow antibiotic and calving.

2-C period. The time period from 2 wk before calving to 1 wk after calving during which three samples were taken.

Intramammary infection: Screening Samples. Isolation of at least one colony of one to three species of bacteria was considered to be an IMI. The presence of more than three bacterial species was 'contaminated' and reculture of the second sample was performed. Infection status was then based on isolation of organisms in the second sample. If the second sample was contaminated, the results were not used in data analysis.

Causes of mastitis. Major pathogen-defined as the mastitis causing organisms; Streptococcus agalactiae, Streptococcus uberis, Streptococcus dysgalactiae, coagulase-positive staphylococci, Escherichia coli, Klebsiella spp., Enterobacter spp., Citrobacter spp., Serratia spp., and Arcanobacterium pyogenes.

Minor pathogen - defined as Corynebacterium spp. and coagulase-negative staphylococci.

Causes of mastitis were defined as follows.

i. A bacterial species in pure growth-causal.

ii. Major pathogen + minor pathogen $(\mathrm{s})-$ major pathogen causal.

iii. More than one major pathogen-mixed etiology, specified by organisms present, both causal.

iv. Greater than three bacteria-contaminated sample.

A quarter with clinical mastitis. Analysis was performed at the quarter level. A quarter with one or more cases of clinical mastitis during the study period was a positive (mastitic) quarter. A cow could have up to four quarters affected. The bacterial species causing clinical mastitis in a quarter was defined as that associated with the first case during lactation.

A nonmastitic quarter. A quarter with no clinical mastitis through the study period. 


\section{Data Recording and Analysis}

Herd, cow, and quarter identity, dates and culture results were entered into a database (Microsoft Access, Microsoft Corp., Redmond, WA, US). Univariate analysis was performed using Microsoft Excel (Microsoft Corp.), Minitab 10.51 (Minitab Inc., State College, PA, US) and EGRET 2.0.3 (Cytel Software Corp., San Diego, CA, US). The associations between bacterial species isolated in screening samples and the incidence of clinical mastitis were assessed at quarter level. This was done initially using Chi square tests (Petrie and Watson, 1999) and then using binomial logistic regression (see below). Single time-point and multiple isolations of the same bacteria through the sample period in each quarter were examined to investigate associations with clinical mastitis. The following patterns of infection were considered independently and together, in relation to clinical mastitis:

i. Each bacterial species at each sample-point.

ii. Presence of a bacterial species in at least one of the three 2-C samples.

iii. Presence of a bacterial species in at least two of the three 2-C samples.

iv. Presence of a bacterial species in at least one of the three 2-C samples without the same species being present at drying off ('New' IMI).

v. Presence of a bacterial species in at least two out of the three 2-C samples when the same species was not present at drying off ('New' IMI).

vi. Presence of a bacterial species both at drying off and in at least one of the 2-C samples ("persistent' IMI).

vii. Presence of Corynebacterium spp. and coagulasenegative staphylococci in the $2-\mathrm{C}$ period without a previous 2-C infection with a major pathogen.

Variables that could influence the relationship between IMI and clinical mastitis (potential confounders) were assessed initially with univariate analysis carried out at quarter level without accounting for clustering of quarters within cows. The effect of farm, calving season, parity, days at risk, length of dry period, and the number of dry period screening samples, on the incidence of clinical mastitis, were investigated using Chi square tests for categorical data and Kruskal Wallis tests for nonparametric continuous data (Petrie and Watson, 1999).

Logistic binomial regression with random effects for distinguishable data (EGRET 2.0.3, Cytel Software Corp.) was used to model the occurrence of clinical mastitis and patterns of bacterial IMI as previously defined. Logistic models were fitted with the outcome (response) variables being:
1. All pathogen types of clinical mastitis considered together ('all clinical mastitis').

2. Clinical E. coli mastitis.

Since there were insufficient cases of mastitis caused by coagulase-positive staphylococci, $S$. dysgalactiae and $S$. uberis to allow pathogen-specific modeling, Chisquare analysis was used to examine the influence of IMI in the sampling period on clinical mastitis.

A random term for cow was included in the models to account for the effect of clustering of quarters within cow. Farm level variation was accounted for by including 'herd' as a fixed effect where this improved the model (see below). Therefore, the model for the response probability $\pi_{\mathrm{ij}}$ for the jth covariate pattern within the ith cluster was:

$$
\operatorname{Logit}\left(\pi_{\mathrm{ij}}\right)=\alpha+\beta_{1} \mathrm{X}_{\mathrm{ijl}}+\ldots \ldots+\beta_{\mathrm{p}} \mathrm{X}_{\mathrm{ijp}}+\sigma \mathrm{u}_{\mathrm{i}},
$$

where $\alpha$ is the intercept, $\beta_{1}$ is the coefficient of covariate $\mathrm{X}_{1}$ and there are $\mathrm{p}$ covariates, and $\sigma \mathrm{u}_{\mathrm{i}}$ is a random term in which $\sigma$ is a positive scalar coefficient (overdispersion parameter). A value of $\sigma=0$ means no overdispersion, and $\sigma>0$ indicates overdispersion. $\mathrm{u}_{\mathrm{i}}$ is a standardized binomial random variable.

Explanatory variables were selected from the univariate analysis if there was a trend to increase or decrease the risk of clinical mastitis $(P<0.25)$ and modeled using a forward stepwise procedure (Hosmer and Lemeshow, 1989, Kleinbaum, 1994). Covariates were left in the model when there was a significant reduction in deviance computed from the likelihood ratio statistic. Potential confounders and a random term for cow were included in the model when there was a biological improvement in the model; a change in the odds ratios or confidence intervals for the covariate coefficients (Hosmer and Lemeshow, 1989; Kleinbaum, 1994). The significance probability was set at 0.05 for a two-tailed test. Interactions between significant covariates remained in the model if there was a significant improvement as judged by the likelihood ratio statistic. When the prevalence of infection for an outcome was zero, which precluded calculation of an odds ratio using normal logistic regression, combinations of time points were used, rather than exact analytical methods, or the variable was removed if it was judged to be of no biological importance. Goodness of fit of the models was assessed from graphs of residuals.

Kaplan-Meier curves were constructed of survival time to clinical mastitis (Parmer and Machin, 1995) in quarters with and without IMI during the dry period. The survival function was calculated as:

$$
\mathrm{S}(\mathrm{t})=\left(1-\mathrm{d}_{1} / \mathrm{n}_{1}\right)\left(1-\mathrm{d}_{2} / \mathrm{n}_{2}\right) \ldots\left(1-\mathrm{d}_{\mathrm{t}} / \mathrm{n}_{\mathrm{t}}\right),
$$


Table 1. Herd distribution of quarters, cows and clinical mastitis used for modeling intramammary infections.

\begin{tabular}{llll}
\hline & $\begin{array}{l}\text { Approximate rolling } \\
\text { herd size (number of } \\
\text { cows in milking herd) }\end{array}$ & $\begin{array}{l}\text { Number of quarters (cows) } \\
\text { sampled at drying off, } \\
\text { during the dry period, } \\
\text { and at calving }\end{array}$ & $\begin{array}{l}\text { Number of } \\
\text { quarters (cows) } \\
\text { with clinical } \\
\text { mastitis }\end{array}$ \\
\hline 1 & 110 & $148(74)$ & $19(18)$ \\
2 & 120 & $131(66)$ & $20(18)$ \\
3 & 100 & $116(58)$ & $14(12)$ \\
4 & 190 & $208(105)$ & $11(11)$ \\
5 & 140 & $179(90)$ & $4(4)$ \\
6 & 150 & $172(87)$ & $84(75)$ \\
TOTAL & & $954(480)$ & $84(75)$ \\
\hline
\end{tabular}

where $\mathrm{n}_{\mathrm{t}}=$ the number of quarters at risk (not yet having mastitis) at the start of time interval $t, d_{t}=$ the number of quarters that got clinical mastitis during time interval $\mathrm{t}$, and $\mathrm{S}(\mathrm{t})=$ the probability of a quarter not getting clinical mastitis by time $t$. Curves were evaluated for statistical differences using the hazard ratio calculated from a Cox Proportional Hazards Model (Parmer and Machin, 1995). As before, the significance probability was set at 0.05 for the likelihood ratio statistic. To check that the assumption of proportionality of hazards between groups was correct, a visual assessment was performed of log-transformed data (Parmer and Machin, 1995).

\section{RESULTS}

A total of 1920 quarters from 480 cows entered the study. A total of 954 quarters were sampled on all four occasions, including during the dry period, and 944 quarters were not sampled during the dry period. Twenty-two quarters were omitted from the analysis because they had one or more missing data points. The distribution between herds of quarters, cows and clinical mastitis available for modeling is shown in Table 1.

Of the 149 cases of clinical mastitis that occurred, 84 were in sampled quarters and 65 in controls. The bacteria isolated from the 84 cases are listed in Table 2 . In $32(38.1 \%)$ of the 84 cases in sampled quarters, the species of bacteria isolated at the time of clinical mastitis were also isolated in at least one of the screening samples. The prevalence of bacterial IMI in the 954 quarters sampled during the dry period is presented in Table 3.

\section{Potential Confounders for the Risk of Clinical Mastitis}

As a result of the sampling protocol, individual quarters were sampled on $0,2,3,4$, or 5 times during the dry period. Repeated sampling occurred when a cow calved later than the expected date. There was an in- creased risk of clinical mastitis in quarters sampled four times compared to quarters not sampled $(P<0.05)$ but no difference between those sampled on 2,3 , or 5 occasions and quarters not sampled.

Considering all herds together, quarters from cows of greater than third parity were at increased risk of clinical mastitis compared with those of parity 3 or less $(P<0.01)$. There was a trend for quarters from cows calving in the summer to have more clinical mastitis than those in spring $(P=0.17)$. Quarters from cows in herds 4 and 5 were at a significantly reduced risk of clinical mastitis compared with herd $1(P<0.01)$.

Quarters with clinical mastitis had significantly fewer days at risk during the study period (mean = 210.9 , median $=229.0 \mathrm{~d}$, interquartile range $=144.3$ to $300.0 \mathrm{~d}$ ) than nonmastitis quarters (mean $=232.8$ median $=261.0$, interquartile range $=169.0$ to 300.0 d), $(P=0.044)$ because clinical mastitis occasionally resulted in premature culling. Since quarters with a case of clinical mastitis had fewer days at risk than other quarters, an increased days at risk was not a cause of an increased probability of clinical mastitis.

Table 2. Bacteria isolated in cases of clinical mastitis from dry period sampled quarters.

\begin{tabular}{ll}
\hline Bacterial species & Number of cases \\
\hline Escherichia coli & 37 \\
No Growth & 9 \\
Streptococcus dysgalactiae & 5 \\
Streptococcus uberis & 5 \\
Coagulase-positive staphylococci & 5 \\
Mixed growth & 3 \\
Serratia spp. & 3 \\
Streptococcus faecalis & 2 \\
Pseudomonas spp. & 2 \\
Bacillus spp. & 2 \\
Yeast & 2 \\
Contaminated & 2 \\
Coagulase-negative staphylococci & 2 \\
Klebsiella spp. & 2 \\
Corynebacterium spp. & 1 \\
Enterobacter spp. & 1 \\
Citrobacter spp. & 1 \\
Total & 84 \\
\hline
\end{tabular}


Table 3. Prevalence of major bacterial isolates (in alphabetical order) during the dry period in 954 quarters used for modeling clinical mastitis.

\begin{tabular}{lccccc}
\hline Bacterial species isolated & & Dry & $8-14$ & $0-7$ & Calving \\
\hline Citerobacter spp. & $\mathrm{n}$ & 0 & 4 & 5 & 2 \\
& $\%$ & 0.0 & 0.4 & 0.5 & 0.2 \\
Coagulase-negative staphylococci & $\mathrm{n}$ & 64 & 136 & 124 & 41 \\
& $\%$ & 6.7 & 14.3 & 13.0 & 4.3 \\
Coagulase-positive staphylococci & $\mathrm{n}$ & 15 & 12 & 13 & 13 \\
& $\%$ & 1.6 & 1.3 & 1.4 & 1.4 \\
Corynebacterium spp. & $\mathrm{n}$ & 341 & 25 & 27 & 16 \\
& $\%$ & 35.7 & 2.6 & 2.8 & 1.7 \\
Escherichia coli & $\mathrm{n}$ & 15 & 38 & 55 & 58 \\
Enterobacter spp. & $\%$ & 1.6 & 4.0 & 5.8 & 6.1 \\
& $\mathrm{n}$ & 4 & 7 & 12 & 3 \\
Klebsiella spp. & $\%$ & 0.4 & 0.7 & 1.3 & 0.3 \\
Serratia spp. & $\mathrm{n}$ & 0 & 3 & 1 & 5 \\
& $\mathrm{n}$ & 0.0 & 0.3 & 0.1 & 0.5 \\
Streptococcus agalactiae & $\%$ & 0.2 & 6 & 2 & 1 \\
Streptococcus dysgalactiae & $\mathrm{n}$ & 0 & 0.6 & 0.2 & 0.1 \\
Streptococcus faecalis & $\mathrm{n}$ & 0.0 & 0.0 & 0 & 0 \\
Streptococcus uberis & $\mathrm{n}$ & 5 & 1 & 0.0 & 0.0 \\
& $\mathrm{n}$ & 22 & 0.1 & 0.2 & 5 \\
& $\mathrm{n}$ & 2.3 & 31 & 36 & 36 \\
& $\%$ & 0.9 & 12 & 3.8 & 3.8
\end{tabular}

Key: Dry - Drying off sample. 8-14 - Sample 8 to $14 \mathrm{~d}$ prior to calving. 0-7 - Sample 0 to $7 \mathrm{~d}$ prior to calving. Calving - Sample 0 to $7 \mathrm{~d}$ post calving. $\mathrm{n}$ - number of isolates. $\%$ - percentage of quarters with an infection.

No effect of the length of the dry period was found on clinical mastitis incidence.

Therefore, the potential confounders considered in the models were the number of dry period samples, herd, parity, and calving season.

\section{Univariate Analysis of Clinical Mastitis and Bacteria Isolated in Screening Samples}

Bacteria present at drying off. When the following bacteria were isolated at drying off, there was a trend for an increased risk of clinical mastitis $(P<0.25) S$. dysgalactiae, S. uberis, $S$. faecalis, coagulase-positive staphylococci, E. coli, Enterobacter spp., Serratia spp., and Corynebacterium spp.

Bacteria present from 2 wh before calving to 1 wh after calving. A trend for increased risk of clinical mastitis $(P<0.25)$ was associated with isolation of $S$. uberis, S. faecalis, coagulase-positive staphylococci, Serratia spp., and Klebsiella spp., 8 to $14 \mathrm{~d}$ before calving and S. dysgalactiae, S. uberis, S. faecalis, coagulasepositive staphylococci, E. coli, Serratia spp., and coagulase negative staphylococci, 0 to $7 \mathrm{~d}$ before calving. Isolation of the following organisms in at least two out of three samples during the 2 -C period was also associated with a trend for an increased risk of clinical mastitis $(P$ $<0.25)$ : S. dysgalactiae, S. uberis, S. faecalis, coagulasepositive staphylococci, E. coli, Serratia spp., Klebsiella spp., and coagulase-negative staphylococci. The presence of Corynebacterium spp. 0 to $14 \mathrm{~d}$ before calving was associated with a decreased likelihood of clinical mastitis $(P<0.25)$. When the following bacteria were isolated in the postcalving sample, there was a trend for an increased likelihood of clinical mastitis: $S$. uberis, coagulase-positive staphylococci, E. coli, and Klebsiella spp. $(P<0.25)$. When Corynebacterium spp. were isolated in the postcalving sample, there was a trend for less clinical mastitis $(P<0.25)$.

\section{Modeling IMI and Clinical Mastitis}

The final clinical mastitis models are presented in Tables 4 and 5 .

When the outcome variable was all cases of clinical mastitis, the probability of a quarter showing clinical mastitis was increased significantly $(P<0.05)$, with the presence of IMI caused by $S$. dysgalactiae, Corynebacterium spp., E. coli, $S$ faecalis, and Enterobacter spp. at drying off. The probability also increased with isolation of E. coli, Serratia spp., coagulase-positive staphylococci, and $S$. faecalis IMI in at least two of the 2-C screening samples in quarters not infected with the same bacteria at drying off. The presence of Corynebacterium spp. in any one of the 2-C samples, in quarters not already infected with a major pathogen in the 2-C period, was associated with a significant reduction in 
Table 4. Logistic binomial regression model with random effect for cow - Model 1: Response variable - all causes of clinical mastitis at quarter level (yes/no); 84 quarters got clinical mastitis out of 954 sampled during the dry period.

\begin{tabular}{|c|c|c|c|c|c|c|c|}
\hline \multirow[b]{2}{*}{ Exposures } & \multirow[b]{2}{*}{$\mathrm{n}$} & \multirow[b]{2}{*}{ Coefficient } & \multirow[b]{2}{*}{ S.E. } & \multirow{2}{*}{$\begin{array}{l}P- \\
\text { value }\end{array}$} & \multirow{2}{*}{$\begin{array}{l}\text { Odds } \\
\text { ratio }\end{array}$} & \multicolumn{2}{|c|}{ 95\% C.I. } \\
\hline & & & & & & lower & upper \\
\hline Intercept $\alpha$ & & -3.18 & 0.50 & & & & \\
\hline \multicolumn{8}{|l|}{ Confounders } \\
\hline Herd 1 & 148 & reference & & & & & \\
\hline Herd 2 & 131 & 0.39 & 0.45 & 0.39 & 1.47 & 0.61 & 3.59 \\
\hline Herd 3 & 116 & 0.06 & 0.45 & 0.90 & 1.06 & 0.43 & 2.58 \\
\hline Herd 4 & 208 & -1.10 & 0.48 & 0.02 & 0.33 & 0.13 & 0.86 \\
\hline Herd 5 & 179 & -2.01 & 0.73 & 0.01 & 0.13 & 0.03 & 0.56 \\
\hline Herd 6 & 172 & -0.25 & 0.43 & 0.57 & 0.78 & 0.34 & 1.82 \\
\hline Parity 2 and 3 & 449 & reference & & & & & \\
\hline Parity 4 and 5 & 342 & 0.59 & 0.33 & 0.08 & 1.81 & 0.94 & 3.48 \\
\hline Parity $>5$ & 163 & 0.85 & 0.38 & 0.03 & 2.33 & 1.10 & 4.95 \\
\hline \multicolumn{8}{|l|}{ Exposures } \\
\hline E. coli D & 15 & 2.99 & 0.81 & $<0.01$ & 19.82 & 4.02 & 97.65 \\
\hline Enterobacter spp. D & 4 & 2.53 & 1.21 & 0.04 & 12.60 & 1.17 & 135.92 \\
\hline Corynebacterium spp. D & 341 & 0.60 & 0.32 & 0.05 & 1.83 & 0.98 & 3.41 \\
\hline S. dysgalactiae D & 5 & 2.45 & 1.16 & 0.05 & 11.56 & 1.18 & 113.23 \\
\hline S. faecalis D & 22 & 1.10 & 0.63 & 0.05 & 3.01 & 0.88 & 10.28 \\
\hline \multicolumn{8}{|l|}{ NEW coagulase-positive } \\
\hline staphylococcus Twice & 7 & 3.26 & 1.08 & $<0.01$ & 25.92 & 3.11 & 215.96 \\
\hline NEW E. coli Twice & 17 & 1.86 & 0.65 & $<0.01$ & 6.41 & 1.79 & 22.94 \\
\hline NEW S. faecalis Twice & 16 & 1.77 & 0.74 & 0.03 & 5.86 & 1.37 & 25.02 \\
\hline NEW Serratia spp. Twice & 2 & 3.29 & 1.71 & 0.05 & 26.84 & 0.95 & 760.38 \\
\hline \multirow{4}{*}{$\begin{array}{l}\text { Corynebacterium spp. and No } \\
\text { Major Pathogen } 2 \text {-C } \\
\sigma \text { (positive scalar coefficient } \\
\text { of random term) } \\
\text { Deviance }=462.1\end{array}$} & & & & & & & \\
\hline & 42 & -1.82 & 1.11 & 0.03 & 0.16 & 0.02 & 1.43 \\
\hline & & 0.72 & 0.49 & & & & \\
\hline & & & & & & & \\
\hline
\end{tabular}

Key: D - isolate present at drying off, regardless of other isolations.

Twice - isolate present in two out of three samples in 2-C period.

$\mathrm{NEW}$ - an isolate present in the 2-C period but not at drying off.

Corynebacterium spp. and No Major Pathogen 2-C - Corrynebacteria spp. isolated at least once in 2-C period without prior infection with a major pathogen in 2 -C period.

Table 5. Logistic binomial regression model with random effect for cow - Model 2: Response variable is clinical E. coli mastitis at quarter level (yes/no); 37 cases occurred in 954 quarters sampled during the dry period.

\begin{tabular}{|c|c|c|c|c|c|c|c|}
\hline \multirow[b]{2}{*}{ Exposures } & \multirow[b]{2}{*}{$\mathrm{n}$} & \multirow[b]{2}{*}{ Coefficient } & \multirow[b]{2}{*}{ S.E. } & \multirow[b]{2}{*}{$P$-value } & \multirow{2}{*}{$\begin{array}{l}\text { Odds } \\
\text { Ratio }\end{array}$} & \multicolumn{2}{|c|}{$95 \% \mathrm{CI}$} \\
\hline & & & & & & lower & upper \\
\hline Intercept $\alpha$ & & -3.26 & 0.64 & & & & \\
\hline \multicolumn{8}{|l|}{ Confounders } \\
\hline Herd 1 & 148 & reference & & & & & \\
\hline Herd 2 & 131 & -0.38 & 0.64 & 0.56 & 0.68 & 0.19 & 2.42 \\
\hline Herd 3 & 116 & -0.92 & 0.76 & 0.22 & 0.40 & 0.09 & 1.76 \\
\hline Herd 4 & 208 & -1.70 & 0.74 & 0.02 & 0.18 & 0.04 & 0.77 \\
\hline Herd 5 & 179 & -2.66 & 0.99 & 0.01 & 0.07 & 0.01 & 0.49 \\
\hline Herd 6 & 172 & -1.27 & 0.69 & 0.07 & 0.28 & 0.07 & 1.08 \\
\hline \multicolumn{8}{|l|}{ Exposures } \\
\hline $\begin{array}{l}\text { E. coli D } \\
\text { Coagulase-positive }\end{array}$ & 15 & 3.43 & 1.13 & $<0.01$ & 30.97 & 3.38 & 283.34 \\
\hline Staphyloccocus D & 15 & 2.32 & 1.05 & 0.03 & 10.14 & 1.29 & 79.76 \\
\hline NEW E. coli Twice & 17 & 3.68 & 0.92 & $<0.01$ & 39.69 & 6.60 & 238.51 \\
\hline $\begin{array}{l}\text { NEW } S \text {. faecalis Twice } \\
\sigma \text { (positive scalar } \\
\text { coefficient of random }\end{array}$ & 16 & 2.50 & 1.05 & 0.02 & 12.15 & 1.56 & 94.52 \\
\hline term) & & 1.48 & 0.65 & & & & \\
\hline
\end{tabular}

Key: D - isolate present at drying off, regardless of other isolations.

Twice - isolate present in two out of three samples in 2-C period.

$\mathrm{NEW}$ - an isolate present in the 2-C period but not at drying off. 
the likelihood of subsequent clinical mastitis. Quarters in cows from herds 4 and 5 were at significantly reduced risk of clinical mastitis compared to herd 1. Quarters in cows of parity greater than 3 were at significantly greater risk of clinical mastitis compared to those of parity 2 to 3 . Calving season and the number of dry period samples taken did not influence the risk of clinical mastitis.

The $E$. coli model indicated that the risk of clinical $E$. coli mastitis was increased with isolation of $E$. coli and coagulase-positive staphylococci at drying off and isolation of $S$. faecalis and $E$. coli at least twice in the $2-\mathrm{C}$ period in quarters not infected with them at drying off (Table 5). Quarters in cows from herds 4 and 5 were at significantly reduced risk of clinical $E$. coli mastitis compared to herd 1 but there was no significant effect of parity, calving season, or the number of dry period samples taken.

The random effect of 'cow' improved both models and was, therefore, included in the models.

The risk of clinical mastitis caused by $S$. uberis, $S$. dysgalactiae, or coagulase-positive staphylococci was significantly increased if the organism causing mastitis was isolated in at least two of the 2-C samples (Table 6).

A graph of fitted values for the model for 'all clinical mastitis' (Figure 1) indicated that quarters with mastitis were more likely to have higher fitted values (i.e., predicted to be a case by the model) than nonmastitic quarters; the model was able to differentiate mastitic and nonmastitic quarters reasonably well.

There was a different pattern of clinical mastitis in quarters that had the same species of bacteria isolated during the screening period and at the time of clinical mastitis (group A), from quarters that did not (group B), as illustrated in Figure 2. Sixty percent of quarters in group A got clinical mastitis within $14 \mathrm{~d}$ of calving compared with $20 \%$ in group B. Over $80 \%$ of mastitis in group A had occurred by d 120 of lactation, whereas only $50 \%$ had occurred by this time in group B. The

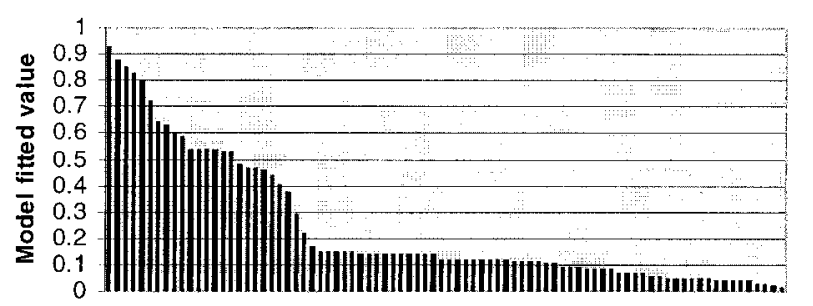

Quarters that got mastitis (descending order of fitted value)

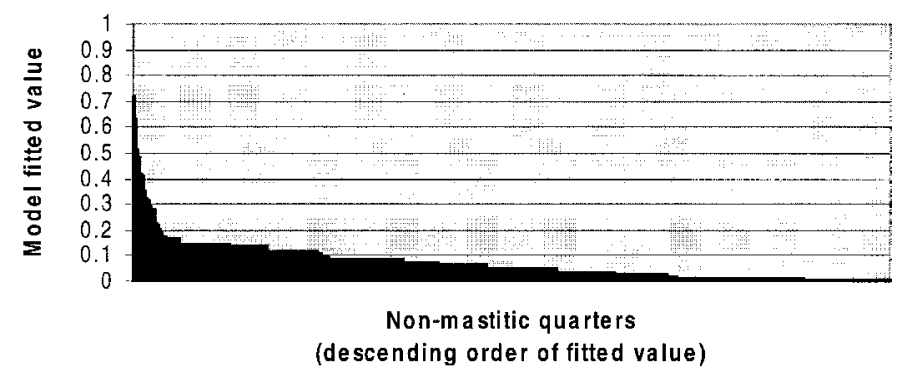

Figure 1. Graphs of fitted values from model 1 (all causes of clinical mastitis) for quarters that got mastitis $(\mathrm{n}=84)$ and those that did not $(n=870)$. Quarters are placed in descending order of fitted value to allow comparison between graphs.

probability of a case of clinical mastitis was fairly constant throughout lactation for group B quarters. The two curves were significantly different, with group A being at an increased hazard of mastitis (Hazard Ratio $=1.86,95 \%$ confidence intervals $=1.17-2.95, P=0.01$ ).

The survival times to mastitis for quarters with Corynebacterium spp. IMI is illustrated in Figure 3. Quarters infected at drying off were more likely to get clinical mastitis at any time during the next lactation compared with uninfected quarters (Hazard Ratio $=1.85$, 95\% confidence intervals $=1.20-2.84, P<0.01$ ). Quarters in which Corynebacterium spp. IMI were found during the 2-C period, with no previous major pathogen IMI during the 2-C period, were less likely to get clinical mastitis during the next lactation compared with quar-

Table 6. The proportion of quarters from which coagulase-positive staphylococci, Streptococcus uberis and Streptococcus dysgalactiae were isolated at least twice in the 2-C period that subsequently got clinical mastitis caused by the respective pathogen.

\begin{tabular}{|c|c|c|c|c|c|c|c|}
\hline \multirow{2}{*}{$\begin{array}{l}\text { Bacteria cultured in } \\
\text { at least two of the } \\
\text { 2-C samples }\end{array}$} & & \multicolumn{2}{|c|}{$\begin{array}{c}\text { Number of quarters with } \\
\text { clinical mastitis (yes or } \\
\text { no) caused by that } \\
\text { species of bacteria }\end{array}$} & \multirow{2}{*}{$\begin{array}{l}\text { Odds } \\
\text { ratio }\end{array}$} & \multicolumn{2}{|c|}{$\begin{array}{l}95 \% \text { Confidence } \\
\text { intervals }\end{array}$} & \multirow{2}{*}{$\begin{array}{l}\text { Chi square } \\
P \text {-value }\end{array}$} \\
\hline & & No & Yes & & lower & upper & \\
\hline \multirow{2}{*}{$\begin{array}{l}\text { Coagulase-positive } \\
\text { staphylococci }\end{array}$} & No & 943 & 2 & & & & \\
\hline & Yes & 6 & 3 & 235.7 & 25.2 & 2612 & $<0.001$ \\
\hline \multirow[t]{2}{*}{ Streptococcus uberis } & No & 941 & 2 & & & & \\
\hline & Yes & 8 & 3 & 176.4 & 19.9 & 1821 & $<0.001$ \\
\hline \multirow{2}{*}{$\begin{array}{r}\text { Streptococcus } \\
\text { dysgalactiae }\end{array}$} & No & 948 & 4 & & & & \\
\hline & Yes & 1 & 1 & 237.0 & 5.3 & 11176 & $<0.001$ \\
\hline
\end{tabular}




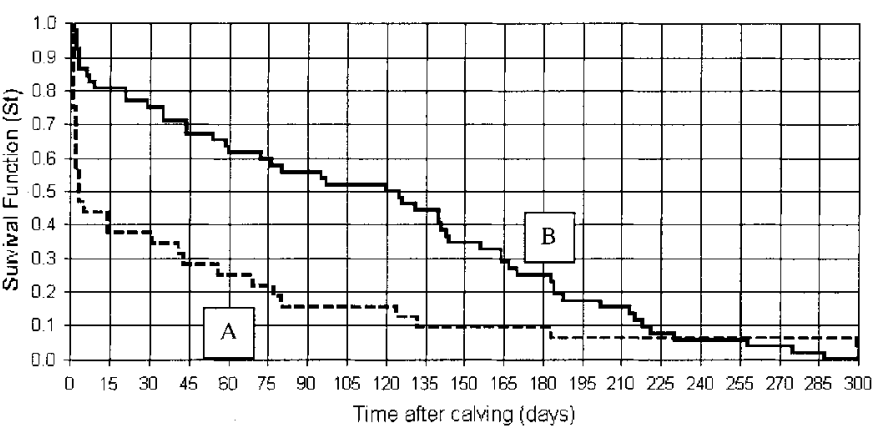

Figure 2. Proportion of quarters without clinical mastitis $(\mathrm{St}=$ survival time) over lactation: A comparison of quarters in which the same pathogen was isolated in the screening period and at the time of clinical mastitis, $n=32(\mathrm{~A})$ and those in which the same pathogen was not isolated in the screening period, $\mathrm{n}=52(\mathrm{~B})$.

ters not infected with Corynebacterium spp. in the 2-C period (Hazard Ratio $=0.21,95 \%$ confidence intervals $=0.03-1.49, P=0.03$ ).

\section{DISCUSSION}

IMI present both at drying off and during the 2-C period increased the risk of clinical mastitis in this study. Late dry-period infections with major pathogens increased the risk of clinical mastitis with the same organism, although it was not possible to determine whether all these bacteria persisted in the mammary gland from the time of dry-period isolation to the time of mastitis, or whether a new infection occurred. Previous work with DNA fingerprinting of the enterobacterial strains in this dataset indicated that persistence of these particular organisms from the dry period to clinical mastitis is likely (Bradley and Green, 2001).

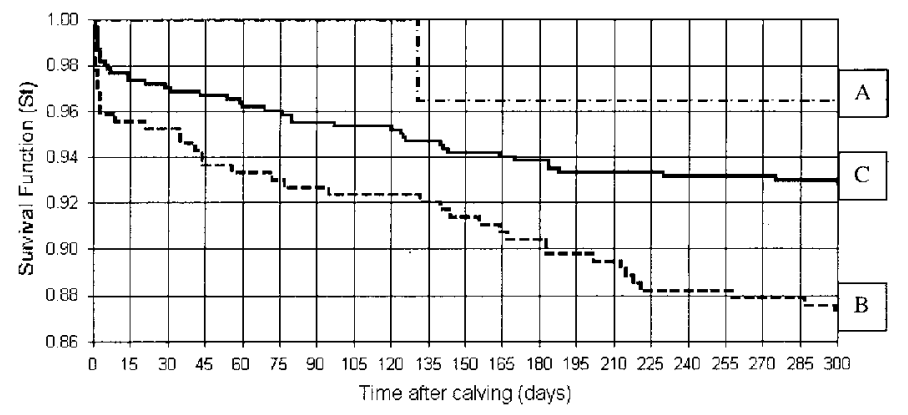

Figure 3. Proportion of quarters without clinical mastitis $(\mathrm{St}=$ survival time) over lactation: A comparison of quarters in which the Corynebacterium spp. was isolated in the 2 -C period without previous isolation of a major pathogen in that period, $\mathrm{n}=42(\mathrm{~A})$, quarters in which Corynebacterium spp. was isolated only at drying off, $n=313$ (B) and quarters in which the Corynebacterium spp. were not isolated at any time, $\mathrm{n}=599(\mathrm{C})$.
Over $60 \%$ of clinical mastitis in quarters in which the same pathogen was identified during the dry period, occurred within 2 wk of calving and $90 \%$ within 150 $\mathrm{d}$ of calving. This is in contrast to the approximately constant rate of clinical mastitis during lactation that occurred in quarters from which the same pathogens were not cultured during the dry period. The pattern and rate of clinical mastitis over lactation on a dairy farm can, therefore, give an indication of the impact of dry period IMI on clinical mastitis and moreover, the areas to target preventive measures.

The presence of $S$. dysgalactiae, S. faecalis, E. coli, Enterobacter spp., and Corynebacterium spp. at drying off increased the probability of subsequent lactational clinical mastitis. The influence of IMI in the 2 -C period on subsequent clinical mastitis was statistically separate from the influence of IMI at drying off since both sample times remained in the models. The data do not support the hypothesis that these organisms persisted from drying off through the dry period since persistence was tested in the models and did not influence the risk of clinical mastitis. Similarly, these findings are unlikely to be a result of contamination of milk samples since the sampling technique was fastidious, sampling during the dry period was always performed by the principle investigators, and there was also no reason that contamination should occur more often at drying off in quarters that got clinical mastitis in the next lactation. One plausible explanation for the increased risk of clinical mastitis in quarters with IMI at drying off is that certain quarters are simply susceptible to IMI. An alternative explanation is that the previous bacterial infection increases the risk of subsequent infection. Quarter susceptibility may occur because of anatomical features such as short wide teat canals (Grega and Szarek, 1985; Grindal et al., 1991) or immunological characteristics, such as poor white cell function (Hill, 1981) or low white cell number (Peeler, 2001). Alternatively, previous infection may cause damage or alteration to the mammary environment in some way and reduce innate defense mechanisms.

An interesting finding in this study was that the timing of IMI with Corynebacterium spp. was important in determining its association with clinical mastitis. If infection was present at drying off, then the quarter was at greater risk of clinical mastitis, and the KaplanMeier curves show that these cases occurred evenly throughout lactation. It is possible that IMI with Corynebacterium spp. occurred because of poor teat hygiene procedures, and this continued into the next lactation and predisposed the quarters to clinical mastitis. Alternatively, it is possible that Corynebacterium spp. IMI at drying off was an indicator of quarters that had poor defense mechanisms such as poor teat closure. This 
would mean these quarters were generally prone to IMI and would be more likely to get clinical mastitis in the next lactation. A previous field study has also found that quarters with Corynebacterium bovis IMI were at an increased risk of subsequent IMI (Hogan et al., 1988).

In this study, however, if Corynebacterium spp. were isolated in the 2-C period, in a quarter not already infected with a major pathogen, then the quarter was at a reduced risk of clinical mastitis. The data, therefore, suggest that the timing of Corynebacterium spp. infection may be important in determining whether a quarter is at greater or reduced risk of clinical mastitis. This may explain why some authors have found protective effects (Lam et al., 1997; Rainard and Poutrel, 1988), while others have found an increase in susceptibility (Hogan et al., 1988). It would be useful to understand the exact conditions that dictate whether infection with Corynebacterium spp. indicates either a more susceptible quarter or a quarter at reduced risk of clinical mastitis. These conditions may include the species and strains of the Corynebacterium involved, the timing of infection, and whether the Corynebacterium spp. IMI is present at the actual time of challenge by a major pathogen.

The clinical value of protection afforded by Corynebacterium spp. in this study was limited. Only 42 out of 954 (4.4\%) quarters were infected with Corynebacterium spp. in the 2-C period, indicating that the vast majority of quarters did not benefit from protection. Since the prevalence of Corynebacterium spp. has been found to decrease in the dry period, even when no antibiotic dry cow therapy is used (Harmon et al., 1986; Oliver and Juneja, 1990), any protective effect is likely to be of value in the field only if methods to safely increase its prevalence are found.

The current study could not determine whether there was a varying level of protection from Corynebacterium spp. IMI to different major pathogens. There were insufficient Corynebacterium spp. infections $(\mathrm{n}=42)$ in the 2-C period to perform this analysis. It remains possible, therefore, that protection may occur for some major pathogens and not others, as has been reported experimentally (Linde et al., 1980; Brooks and Barnum, 1984; Pankey et al., 1985; Doane et al., 1987).

$S$. faecalis IMI in the 2-C period was also a risk factor for clinical mastitis (Model 1). Again, this may be an indicator of increased quarter susceptibility to IMI, or it may be a result of synergistic action between $S$. faecalis and other organisms, particularly E. coli, for which it increased the risk of clinical mastitis (Model 2). Previous reports have suggested that there is more likely to be competition and exclusion, however, rather than synergy between $S$. faecalis and E. coli (Dalhoff, 1982).
Further research into the interactions between $S$. faecalis and other pathogenic bacteria in the mammary gland may be fruitful, but these data suggest that $S$. faecalis may not necessarily be indicative of a contaminated milk sample, as would commonly be reported from UK laboratories.

Data from this study highlight the difficulties of defining IMI. Previous longitudinal studies have defined an IMI as present when a pathogen is cultured on two out of three occasions from consecutive samples 1 to 30 d apart (Smith et al., 1985; Hogan et al., 1988; Lam et al., 1997). This definition is likely to represent longterm infections and will miss those that are transient. Various combinations of IMI were considered in this study; single infections, at least one infection in three consecutive 2-C period samples, and at least two infections in three consecutive 2-C period samples. While two infections out of three samples was the best indicator of clinical mastitis in the models, it was found that this definition of an IMI gave a greater specificity and predictive value for clinical mastitis but a poorer sensitivity than including single infections. This is likely to be because while some single bacterial isolates can lead to clinical mastitis, many will be removed by cow defenses without the appearance of clinical signs.

The use of a single milk sample at drying off to diagnose IMI, rather than two or three, will have reduced the sensitivity of IMI diagnosis. It is considered that false-negative samples are most likely to occur with coliforms and coagulase-positive staphylococci (National Mastitis Council, 1999), although it has been estimated that a single quarter milk sample from a lactating gland has 75 to $90 \%$ sensitivity and $>97 \%$ specificity for diagnosis of coagulase-positive staphylococci IMI (Sears et al., 1990; Buelow et al., 1996). Under diagnosis of true IMI at drying off in this study will have caused an underestimate of the importance of IMI at this time and an overestimate of IMI considered to be 'new' in the 2-C period. False-negative coliform cultures were reduced by using $0.1 \mathrm{ml}$ secretion instead of $0.01 \mathrm{ml}$ (National Mastitis Council, 1999). While recognizing the constraints of bacteriological culture, both total IMI in the 2-C period and apparent new IMI were modeled and it was found that only the new IMI remained in the models. Although not all of these may be truly new IMI, this supports the view that new IMI in the dry period are important (Smith et al., 1985; Eberhart, 1986; Todhunter et al., 1991).

The graphs of fitted values (prediction by the model for each quarter to get mastitis or not) showed a reasonably good differentiation between mastitic and normal quarters (Figure 1). The relatively high fitted values $(>0.2)$ for mastitic quarters related to quarters with dry period IMI and the lower values to quarters with 
mastitis not associated with dry period IMI. The model could not predict all quarters that got mastitis, and this was expected because not all clinical mastitis was not associated with dry period IMI. The number of quarters (32 out of 84), however, in which clinical mastitis was associated with IMI by the same organism during the sampling period, was surprisingly high. The model could differentiate quarters that did not get mastitis as shown by low fitted values, and this indicated that few of these non-mastitis quarters had dry period IMI.

Confounders, such as parity and herd, were included in the logistic regression analysis to control for variation that may affect the relationship between dry period IMI and clinical mastitis. This meant that estimates of the coefficients of the explanatory variables were adjusted and of greater accuracy (Hosmer and Lemeshow, 1989; Kleinbaum, 1994). Herd and parity were the only confounders identified in the final models, and it is noteworthy that quarters from cows of parity greater than 3 were at approximately twice the risk of clinical mastitis compared to those of parity 2 and 3 . Cows of parity 1 did not participate in the study because they did not have a dry period. There was a small increase in the proportion of quarters that got clinical mastitis when sampled during the dry period compared to those not sampled. This was mainly because of an increased risk in quarters sampled four times during the dry period. The number of dry period samples taken was, therefore, used as a covariate for modeling clinical mastitis, but it did not remain in any model, indicating that sampling did not significantly influence the risk of clinical mastitis.

Improvement of the models with the inclusion of a random term for cow indicated that quarters within a cow were not behaving independently. That is, two quarters of the same cow were more likely to show similar patterns of IMI and clinical mastitis than two quarters of different cows. Correcting for this potential bias in the data improved the accuracy of the confidence intervals in the model and shows that this is an important consideration when handling quarter level mastitis data from dairy cows.

\section{CONCLUSIONS}

The results demonstrate that IMI during the dry period is an important influence on subsequent clinical mastitis. IMI with major pathogens in the late, dry, and post-calving period increase the risk of clinical mastitis, and this mastitis occurs at a greater rate after calving than mastitis not associated with dry period infections. Isolation of Corynebacterium spp. was associated with both an increase and a decrease in clinical mastitis, depending on the timing of infection. There was evi- dence of quarter susceptibility to IMI or the possibility that infection with one organism may lead to clinical mastitis with another. Future research on preventing dry period IMI, the protective effects of Corynebacterium spp., quarter susceptibility, and interactions between consecutive IMI with different bacteria may improve our ability to reduce clinical mastitis.

\section{ACKNOWLEDGMENTS}

We would like to thank the farmers and herdspersons involved in the study and the financial support of Leo Animal Health UK, Ltd. M. J. Green is supported by a BBSRC case studentship, and A. J. Bradley is supported by a Wellcome Trust fellowship.

\section{REFERENCES}

Bradley, A. J., and M. J. Green. 2000. A study of the incidence and significance of intramammary enterobacterial infections acquired during the dry period. J. Dairy Sci. 83:1957-1965.

Bradley, A. J., and M. J. Green. 2001. Clinical mastitis in a cohort of Somerset dairy herds. Vet. Rec. 148:683-686.

Bramley, A. J. 1976. Variations in the susceptibility of lactating and non-lactating bovine udders to infection when infused with Escherichia coli. J. Dairy Res. 43:205-211.

Brooks, B. W., and D. A. Barnum. 1984. Characterization of strains of Corynebacterium bovis. Can. J. Comp. Med. 48:(2)230-232.

Buelow, K. L., C. B. Thomas, W. J. Goodger, K. V. Norland, and M. T. Collins. 1996. Effect of milk sample collection strategy on the sensitivity and specificity of bacteriologic culture and somatic cell count for detection of coagulase-positive staphylococci intramammary infection in dairy cattle. Prev. Vet. Med. 26:1-8.

Dalhoff, A. 1982. Influence of Escherichia coli on Streptococcus faecalis in mixed cultures and experimental animal infections. Eur. J. Clin. Microbiol. 1:17-21.

Doane, R. M., S. P Oliver, R. D. Walker, and E. P. Shull. 1987. Experimental infection of lactating bovine mammary glands with Streptococcus uberis in quarters colonized by Corynebacterium bovis. Am. J. Vet. Res. 48:749-54.

Eberhart, R. J. 1986. Management of dry cows to reduce mastitis. J. Dairy Sci. 69:1721-1732.

Eberhart, R. J., and J. M. Buckalew. 1977. Intramammary infections in a dairy herd with a low incidence of Streptococcus agalactiae and Staphylococcus aureus infections. J. Am. Vet. Med. Assoc. 1;171: 630-634.

Goldstein, H. 1995. Multilevel Statistical Models (second edition). Edward Arnold, London, UK.

Grega, T., and J. Szarek. 1985. Relationship of teat canal size to milkability and udder health in three breeds. Zeszyty Naukowe Akademii Rolniczej $w$ Krakowie No. 191. Zootechnika 23:3-11.

Grindal, R. J., A. W. Walton, and J. E. Hillerton. 1991. Influence of milk flow rate and teat canal length on new intramammary infection in dairy cows. J. Dairy Res. 58:383-388.

Harmon, R. J., W. L. Crist, R. W. Hemken, and B. E. Langlois. 1986. Prevalence of minor udder pathogens after intramammary dry treatment. J. Dairy Sci. 69:843-849.

Hill, A. W. 1981. Factors influencing the outcome of Escherichia coli mastitis in dairy cows. Res. Vet. Sci. 31:107-112.

Hogan, J. S., K. L. Smith, D. A. Todhunter, and P. S. Schoenberger. 1988. Rate of environmental mastitis in quarters infected with Corynebacterium bovis and Staphylococcus species. J. Dairy Sci. $71: 2520-2525$.

Hosmer, D. W., and S. Lemeshow. 1989. Applied Logistic Regression. John Wiley and Sons, Inc. New York. USA.

Kleinbaum, D. G. 1994. Logistic Regression. Statistics in Health Sciences. Springer Verlag New York, Inc. New York. USA. 
Kossaibati, M. A., and R. J. Esslemont 1997. The costs of production diseases in dairy herds in England. Veterinary Journal. 154:41-51.

Kossaibati, M. A., M. Hovi, and R. J. Esslemont. 1998. Incidence of clinical mastitis in dairy herds in England. Vet. Rec. 143: 649-653.

Lam, T. J., Y. H. Schukken, J. H. van Vliet, F. J. Grommers, M. J. Tielen, and A Brand. 1997. Effect of natural infection with minor pathogens on susceptibility to natural infection with major pathogens in the bovine mammary gland. Am. J. Vet. Res. 58:17-22.

Linde, C., O. Holmberg, and G. Anstrom. 1980. The interference between coagulase negative-staphylococci and Corynebacterium bovis and the common udder pathogens in the lactating cow. Nord. Veterinaermed. 32:552-558.

McDermott, J. J., and Y. H. Schukken. 1994. A review of methods used to adjust for cluster effects in explanatory epidemiological studies of animal populations. Prev. Vet. Med. 18:155-173.

McDonald, J. S., and A. J. Anderson. 1981. Experimental intramammary infection of the dairy cow with Escherichia coli during the non-lactating period Am. J. Vet. Res. 42:229-231.

National Mastitis Council. 1999. Laboratory Handbook on Bovine Mastitis. National Mastitis Council, Inc. Madison, WI, USA

Neave, F. K., F. H. Dodd, and E. Henriques. 1950. Udder infections in the dry period. J. Dairy Res. 17:37-49.

Oliver, J., K. F. Neave, and M. E. Sharpe. 1962. Prevention of infection of the dry udder. J. Dairy Res. 29:95-104.

Oliver, S. P., and B. A. Michell. 1983. Susceptibility of bovine mammary gland to infections during the dry period. J. Dairy Sci. 66: $1162-1166$.

Oliver, S. P. 1988. Frequency of isolation of environmental mastitiscausing pathogens and incidence of new intramammary infection during the non-lactating period. Am. J. Vet. Res. 49:(11) 17891793.
Oliver, S. P., and V. K. Juneja. 1990. Growth of Corynebacteriun bovis in mammary secretions during physiological transitions of the bovine mammary gland. J. Dairy Sci. 73:351-356.

Pankey, J. W., S. C. Nickerson, R. L. Boddie, and J. S. Hogan. 1985. Effects of Corynebacterium bovis infection on susceptibility on major mastitis pathogens. J. Dairy Sci. 68:2684-2693.

Parmer, K. B., and D. Machin. 1995. Survival Analysis-A practical approach. John Wiley and Sons, NY. USA.

Peeler, E. J. 2001. Epidemiological studies of clinical mastitis in British dairy herds with bulk milk somatic cell counts of less than 150,000/mL. Ph.D. Thesis, Univ. Bristol, UK.

Petrie, A., and P. Watson. 1999. Statistics for Veterinary and Animal Science, Blackwell Science, Ltd., Oxford, UK.

Quinn, P. J., M. E. Carter, B. Markey, and G. R. Carter. 1994. Clinical Veterinary Microbiology. Wolfe, London, UK.

Rainard, P., and B. Poutrel. 1988. Effect of naturally occurring intramammary infections by minor pathogens on new infections by major pathogens in cattle. Am. J. Vet. Res. 49(3):327-329.

Sears, P. M., B. S. Smith, P. B. English, P. S. Herer, and R. N. Gonzalez. 1990. Shedding patterns of Staphylococcus aureus from the bovine intramammary infections. J. Dairy Sci. 73:2785-2789.

Smith, A., F. H. Dodd, and F. K. Neave. 1968. The effect of intramammary infection during the dry period on the milk production of the affected quarter at the start of the succeeding lactation. J. Dairy Res. 35:287-294.

Smith, K. L., D. A. Todhunter, and P. S. Schoenberger. 1985. Environmental pathogens and intramammary infection during the dry period. J. Dairy Sci. 68:402-417.

Todhunter, D. A., K. L. Smith, J. S. Hogan, and P. S. Schoenberger. 1991. Gram-negative bacterial infections of the mammary gland in cows. Am. J. Vet. Res. 52:184-188. 